\title{
Acute Phase Proteins and their Relation to Energy Metabolites in Dairy Cows during the Pre- and Postpartal Period
}

\author{
Gabriel Kováč, Csilla Tóthová, Oskar Nagy, Herbert Seidel, Jana Konvičná \\ Clinic for Ruminants, University of Veterinary Medicine, Košice, Slovak Republic
}

Received May 28, 2008

Accepted February 9, 2009

\begin{abstract}
The objective of this study was to evaluate the concentrations of selected acute phase proteins - haptoglobin (Hp) and serum amyloid A (SAA), and selected variables of energy metabolism in blood serum of dairy cows during different stages of the pre- and postpartal period. The analyses were performed in dairy cows of the Slovak spotted breed and its crossbreeds $(n=57)$. The cows were divided into 9 groups according to the evaluated part of reproduction cycle - from 4 weeks before parturition to 10 weeks after parturition. Significant differences were found in mean $\mathrm{Hp}$ and SAA concentrations during the monitored period $(P<0.05$ and $P<0.001$, respectively). Cows during the early postparturient period had significantly higher Hp and SAA concentrations compared to cows in later postparturient period $(P<0.05)$. Significant differences throughout the period under study was found also in means of total cholesterol $(P<0.01)$, triglycerides $(P$ $<0.001)$, and non-esterified fatty acids $(P<0.001)$. Concentrations of Hp during this period were positively correlated with SAA $(\mathrm{R}=0.919 ; P<0.001)$. Moreover, significant correlations were found between $\mathrm{Hp}$ and non-esterified fatty acids, $\mathrm{Hp}$ and $\beta$-hydroxybutyrate, as well as between SAA and non-esterified fatty acids. Our results indicate that the acute phase response occurs in cows around parturition, and suggest that there are relationships between mediators of immune response and several indices of energy metabolism. Our results also suggest that in cows with higher concentrations of non-esterified fatty acids, indicating a certain degree of lipid mobilisation, higher values of acute phase proteins may be found.
\end{abstract}

Haptoglobin, serum amyloid A, energy balance, cows, periparturient period

The transition of pregnancy to lactation, with the concomitant negative energy balance during early lactation, requires substantial adaptation of the cow, including metabolic and physiological adaptations and changes in metabolism (Hachenberg et al. 2007). Animals react to disturbances in their homeostasis with a set of physiological changes known as the acute phase response (Piňeiro et al. 2003). This defence mechanism is characterized by systemic reactions like fever, alterations of appetite, and decreased serum concentrations of iron and zinc. The most striking phenomenon, however, is the changing concentration in a number of serum proteins, particularly acute phase proteins (APPs) (Petersen et al. 2004). The acute phase proteins that play an important role in the reproductive processes and reconstruction of the endometrium in cattle are haptoglobin $(\mathrm{Hp})$ and serum amyloid $\mathrm{A}$ (SAA) (Krakowski and Zdzisińska 2007). On account of their opsonization properties, both proteins intensify the phagocytosis process against the pathogens introduced into the uterus during fertilization and play an active role in the reconstruction of the tissues damaged during inflammation (Regassa and Noakes 1999).

Most research on APPs is focused on humans. It has been described in women that parturition induces an acute phase protein reaction (Gatzka et al. 2002). The concentrations of most of APPs do not change during pregnancy, but increase at delivery (Berkova et al. 2001). Consequently, the changes in concentration of APPs around the time of parturition are less well-documented for domestic animals. Therefore, the objective of this study was to measure the concentrations of selected APPs - Hp and SAA in different stages of pre- and postpartal periods in relation to possible peripartal disturbances. Moreover,

Address for correspondence:

Prof. MVDr. Gabriel Kováč, DrSc.

Clinic for Ruminants

University of Veterinary Medicine

Komenského 73

04181 Košice, Slovak Republic

Phone: + 421915984597

Fax: +421552981011

E-mail: kovac@uvm.sk

http://www.vfu.cz/acta-vet/actavet.htm 
we hypothesized that activation of the immune response around parturition, as evidenced by the presence of the acute phase response indicators, might be related to changes in energy metabolism. The aim of the study, therefore, was to investigate also the correlations between aforementioned APPs and indices of energy metalbolism.

\section{Materials and Methods}

Selected acute phase proteins - Hp and SAA, and variables of energy metabolism - glucose (Gluc), total cholesterol (TCH), triglycerides (TG), total lipids (TL), non-esterified fatty acids (NEFA), and $\beta$-hydroxybutyrate (BHB) were evaluated in 57 clinically healthy dairy cows of the Slovak spotted breed and its crossbreds. The animals were fed individual feeding rations according to the phase of lactation and milk production. The cows were divided into 9 groups according to stages of pre- and postpartal period as follows:

- Group 1 - dairy cows 4 weeks before parturition $(n=6)$

- Group 2 - dairy cows 1 week before parturition $(n=8)$

- Group 3 - dairy cows 1 week after parturition $(n=5)$

- Group 4 - dairy cows 2 weeks after parturition $(\mathrm{n}=11)$

- Group 5 - dairy cows 3 weeks after parturition $(n=5)$

- Group 6 - dairy cows 4 weeks after parturition $(n=5)$

- Group 7 - dairy cows 5 weeks after parturition $(n=5)$

- Group 8 - dairy cows 8 weeks after parturition $(n=6)$

- Group 9 - dairy cows 10 weeks after parturition $(n=6)$.

Before each sample collection, the animals were clinically examined by standard clinical examination procedures (Kováč et al. 2001). The blood samples were collected by direct puncture of v. jugularis. Blood serum was analyzed for selected acute phase proteins and variables related to energy metabolism.

The values of Gluc, TCH, TG and BHB were assessed using commercial diagnostic kits (Randox) on automatic biochemical analyser (Alizé, Lisabio). Total lipids were analyzed using commercial diagnostic kits (Ecomed) by spectrophotometric method. The concentrations of NEFA were assessed according to Curtius (1974) by spectrophotometric method. The determination of Hp and SAA were performed by the method of enzyme linked immunosorbent assay using ELISA kits (Tridelta Development, Ltd., Wicklow, Ireland).

The evaluation of results was performed by assessment of means (x) and standard errors (SE) in each monitored group of cows, as well as least squares means (LSM) for each variable. The significance of differences in means in relation to monitored periods was evaluated by one-way analysis of variance (ANOVA). The significance of differences in means between the groups was evaluated by Tukey-Kramer Multiple Comparisons Test. Relationship between monitored variables, including Pearson $(\mathrm{R})$ correlation coefficients, and significance of correlations were calculated. Statistical analyses were done using the program GraphPad Instat V2.04.

\section{Results}

The results of $\mathrm{Hp}$ and SAA concentrations and concentrations of variables of energy metabolism are summarised in Table 1 . The analyses of correlations between variables are listed in Table 2.

The mean values of Hp and SAA during the period under study in cows ranged from 34 to $374 \mu \mathrm{g} / \mathrm{ml}$, and 6 to $151 \mu \mathrm{g} / \mathrm{ml}$, respectively. The highest values we recorded in cows 1 week after parturition (Group 3), the values determined in animals in later postparturient period were significantly lower $(P<0.05)$. The differences of means of presented variables in periods of reproduction were significant (ANOVA; $P<0.05$ and $P<0.001$ ). We did not find significant differences in the mean serum concentrations of glucose. The serum concentrations of TCH and TL in later postparturient period (Group 6 -9) were higher than before and shortly after calving. The differences in mean concentrations of $\mathrm{TCH}$ during evaluated periods were significant (ANOVA; $\mathrm{P}<0.01$ ), whereas in serum concentrations of TL we did not find significant changes. The most considerable changes of average values throughout the monitored period we found in concentrations of TG and NEFA $(P<0.001)$. The highest average concentration of TG was recorded in cows 4 weeks before parturition (Group 1). In the next period we observed a trend of lower values, with lowest TG concentrations in cows $5-10$ weeks after the parturition (Group 7 -9). The highest average concentration of NEFA was recorded in cows 1 week post partum (Group 3). The mean values of non-esterified fatty acids in the later postparturient period were significantly lower. The highest BHB concentration was found in cows 1 week before and 1 week after parturition (Group 2 and 3), in the next period we observed a trend of lower 


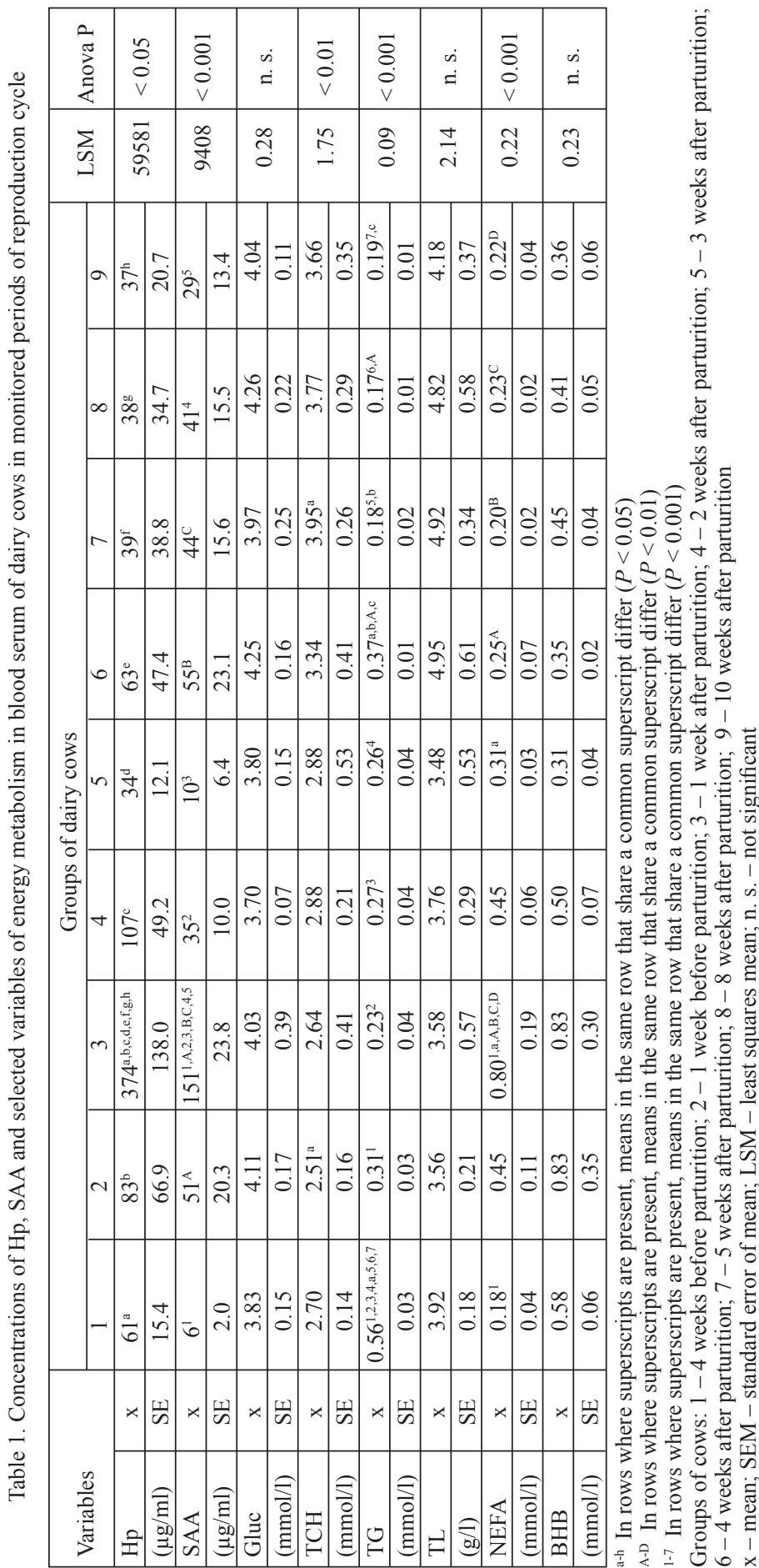

values. However, the differences in mean concentrations of $\beta$-hydroxybutyrate were not significant.

By assessment of correlations of changes in means (Table 2) between monitored acute phase proteins and several variables of energy metabolism in the evaluated period we recorded a significant correlation between $\mathrm{Hp}$ and NEFA ( $\mathrm{R}=$ 0.927; $P<0.001)$, Hp and $\mathrm{BHB}(\mathrm{R}=0.691$; $P<0.05)$, as well as between SAA and NEFA $(\mathrm{R}=0.847 ; P$ $<0.01$ ). Significant correlation was found also between $\mathrm{Hp}$ and SAA $(\mathrm{R}=0.919 ; P<$ 0.001). By evaluation of correlation between variables of energy metabolism in the mentioned time we found significant positive correlation between TCH and TL (R=0.851; $P<0.01)$, and between NEFA and $\mathrm{BHB}(\mathrm{R}=0.726$; $P<0.05)$.

\section{Discussion}

Kinetic variables of APPs during pregnancy and delivery have been studied in great details in humans (Berkova et al. 2001). De Villiers et al. (1990) reported that in cattle, around the time of parturition, the concentrations of 
Table 2. The correlation between selected acute phase proteins and variables of energy metabolism

\begin{tabular}{|l|c|c|c|c|c|c|c|c|}
\hline & Hp & SAA & Gluc & TCH & TG & TL & NEFA & BHB \\
\hline Hp & - & $0.919^{\mathrm{c}}$ & -0.012 & -0.474 & -0.081 & -0.409 & $0.927^{\mathrm{c}}$ & $0.691^{\mathrm{a}}$ \\
\hline SAA & $0.919^{\mathrm{c}}$ & - & 0.320 & -0.212 & -0.290 & -0.116 & $0.847^{\mathrm{b}}$ & 0.621 \\
\hline Gluc & -0.012 & 0.320 & - & 0.392 & -0.237 & 0.586 & -0.082 & -0.019 \\
\hline TCH & -0.474 & -0.212 & 0.392 & - & -0.544 & $0.851^{\mathrm{b}}$ & -0.596 & -0.656 \\
\hline TG & -0.081 & -0.290 & -0.237 & -0.544 & - & -0.195 & -0.186 & 0.172 \\
\hline TL & -0.409 & -0.116 & 0.586 & $0.851^{\mathrm{b}}$ & -0.195 & - & 0.584 & -0.511 \\
\hline NEFA & $0.927^{\mathrm{c}}$ & $0.847^{\mathrm{b}}$ & -0.082 & -0.596 & -0.186 & 0.584 & - & $0.726^{\mathrm{a}}$ \\
\hline BHB & $0.691^{\mathrm{a}}$ & 0.621 & 0.019 & -0.656 & 0.172 & -0.511 & $0.726^{\mathrm{a}}$ & - \\
\hline
\end{tabular}

a, b, c indexes show statistical significance of correlations: ${ }^{\mathrm{a}}-P<0.05 ;{ }^{\mathrm{b}}-P<0.01 ;{ }^{\mathrm{c}}-P<0.001$

APPs are similar to the concentration pattern in humans. Krakowski and Zdzisińska (2007) investigated heifers during the whole pregnancy period and then over the course of 14 days after the delivery, and in the first and second pregnancy trimesters, the Hp and SAA concentrations were either undetectable or very low. The presence of aforementioned indicators in the serum was found in the third pregnancy trimester, at which their highest concentrations were recorded after the delivery. Uchida et al. (1993) observed significantly higher concentrations of $\mathrm{Hp}$ around parturition than before and after calving. Ametaj et al. (2005) found also an increase of two main bovine acute phase proteins, Hp and SAA, immediately after parturition. Alsemgeest et al. (1993) reported that in cows, 48 $\mathrm{h}$ before delivery, the mean SAA concentration was low. According to their results at 24, 48, 72, and $96 \mathrm{~h}$ after delivery, mean SAA concentrations were significantly increased; the highest concentration of SAA was reached $48 \mathrm{~h}$ after calving. Our results comply with these findings, as in cows shortly after calving we found significantly higher Hp and SAA concentrations than before parturition and in later postpartal period.

The most potent stimulus for acute phase protein production is infection or inflammation (Petersen et al. 2004). However, cows shortly after calving, evaluated in our study, were healthy and did not show fever or other signs of general infection. According to Als em geest et al. (1993), the physiological processes taking place around the time of parturition are mainly responsible for the elevated concentrations of SAA. Regassa and Noakes (1999) reported that higher values of APPs could be related to tissue damage occurring due to the increased myometrial activity during expulsion of the calf, and to the involution of the uterus. Young et al. (1995) found that the elevated Hp concentrations, determined in the last phase of pregnancy and after delivery may be connected with the changing hormone profile (the influence of estrogens and progesterone). It is worth pointing out that the increase in Hp concentration in cattle is also caused by the increased concentration of cortisol (Alsemgeest et al. 1996). The fact of the increased SAA concentrations can be interpreted in a similar way. On the other hand, acute metritis and mastitis can also trigger an acute phase response and the synthesis of APPs in the liver, but this increase is more marked (Kováč et al. 2007). Hirvonen et al. (1999) observed clinically healthy cows after calving and cows with acute postpartum metritis. In cows with a systemic acute metritis they found higher Hp concentrations than in controls.

The acute phase response is associated with numerous changes in lipid and glucose metabolism, such as decreased cholesterol, accelerated lipolysis, and increased NEFA in plasma (Hardardottir et al. 1994). Blood glucose increases during the first stage of the acute phase response followed by a sustained hypoglycaemia (Kushibiki et al. 2000). Moreover, propionate production from the low feed intake during the early postpartal period is insufficient to synthesize the total amount of glucose needed (Drackley et al. 2001). Ametaj (2005) observed cows from 4 days before until 36 days after calving, and recorded 
lower glucose concentrations in the early postparturient period, with a significant increase on the $27^{\text {th }}$ day post partum. Our results comply with these findings, as around calving we found lower mean values of glucose compared with cows in the later postparturient period. Elitok et al. (2006) reported that decreased serum glucose concentrations around parturition probably reflect the increasing demands of the foetus and the mammary gland for glucose.

Our results also show high prepartal concentrations of plasma TG, in cows 4 weeks before parturition we found their significantly higher values than in cows shortly after calving. Ametaj et al. (2005) reported also high TG concentrations in cows in prepartal period and a sharp drop immediately after parturition. Triacylglycerides are carried in plasma as lipoproteins. Endotoxins released by Gram-negative bacteria bind to all lipoprotein classes (Levels et al. 2001). The main source of endotoxin in transition dairy cows is their gastrointestinal tract. Feeding cows high proportions of concentrate is associated with an increase of up to 20-fold in the amount of endotoxin in the rumen (Jacobsen 2003). Endotoxin is transferred to blood and cleared by liver macrophages (Harris et al. 2002). Liver macrophages produce TNF- $\alpha$, IL-1 and IL- 6 in response to the presence of endotoxin in blood, which stimulate hepatocytes to release APPs such SAA and Hp (Jacobsen 2003). Based on the changes that occur in cows in response to activation of the acute phase response, Ametaj (2005) proposed that fatty liver developed in response to non-specific inflammation around parturition. Specifically, endotoxins are neutralised by SAA, which is associated with lipoproteins. As TG were taken up into the liver as a component of lipoproteins, fatty liver would result from re-esterifying of fatty acids arising from uptake of TG-containing lipoproteins (Drackley et al. 2007).

The highest NEFA concentrations were observed in cows shortly after calving. Moreover, both investigated APPs correlated positively with non-esterified fatty acids. Recent investigations show that administration of $\mathrm{TNF} \alpha$ to experimental animals is associated with decreased appetite and cachexia, and increased release of NEFA from adipose tissue into plasma (Kushibiki et al. 2002). Therefore, a higher concentration of NEFA in serum could be related to activation of the immune system. Ametaj et al. (2005) reported that increased concentrations of $\mathrm{Hp}$ and SAA after parturition correlate positively with total lipids in the liver.

Our results suggest the presence of the acute phase response in cows around parturition and indicate relationships between mediators of acute phase response and some variables of energy metabolism. In the mentioned period we recorded significant correlations between haptoglobin and non-esterified fatty acids, haptoglobin and $\beta$-hydroxybutyrate, as well as between serum amyloid A and non-esterified fatty acids.

\section{Proteíny akútnej fázy a ich vzt'ah k ukazovatel'om energetického metabolizmu u dojníc počas pre- a postpartálneho obdobia}

Zámerom práce bolo sledovanie koncentrácie vybraných proteínov akútnej fázy - haptoglobínu (Hp) a sérového amyloidu A (SAA), a niektorých ukazovatel'ov energetického metabolizmu v krvnom sére dojníc v rôznych obdobiach pre- a postpartálneho obdobia. Analýzy boli vykonané u dojníc slovenského strakatého dobytka a jeho krížencov $(\mathrm{n}=57)$, ktoré boli rozdelené do 9 skupín podl'a sledovaných období reprodukčného cyklu od 4 týždňov pred pôrodom do 10 týždňov po pôrode. Zaznamenali sme významné rozdiely priemerných hodnôt koncentrácie Hp a SAA v jednotlivých skupinách počas sledovaného obdobia $(P<0,05$, resp. $P<0,001)$. Koncentrácie Hp a SAA v ranom popôrodnom období boli signifikantne vyššie v porovnaní s neskorším postpartálnym obdobím $(P<0,05)$. Počas sledovania sme zistili významné rozdiely aj v priemerných hodnotách celkového cholesterolu $(P<0,01)$, triglyceridov $(P<0,001)$ a neesterifikovaných mastných kyselín $(P<0,001)$. Koncentrácie Hp počas sledovaného obdobia pozitívne korelovali s hodno- 
tami SAA $(\mathrm{R}=0,919 ; P<0,001)$. Okrem toho významnú koreláciu sme zistili medzi Hp a neesterifikovanými mastnými kyselinami, Hp a $\beta$-hydroxybutyrátom, ako aj medzi SAA a neesterifikovanými mastnými kyselinami. Naše výsledky naznačujú, že u dojníc okolo pôrodu dochádza k odpovedi akútnej fázy zápalu a poukazujú na vzájomné vzt’ahy medzi vybranými mediátormi imunologických odpovedí a niektorými ukazovatel'mi energetického metabolizmu. Naše výsledky tiež naznačujú, že u dojníc s vyššími koncentráciami neesterifikovaných mastných kyselín, čo poukazuje na určitý stupeň lipomobilizácie, súčasne sa zist'ujú vyššie koncentrácie proteínov akútnej fázy.

\section{Acknowledgments}

This work was supported by the Slovak Research and Development Agency under contract No APVV-20027905 .

\section{References}

Alsemgeest SPM, Taverne MAM, Boosman R, Van Der Weyden B, Gruys E 1993: Peripartum acute-phase protein serum amyloid-A concentration in plasma of cows and fetuses. Am J Vet Res 54: 164-167

Alsemgeest SPM, Vant Clooster GAE, Van Miert ASJPAM, Hulskamp-Koch CK, Gruys E 1996: Primary bovine hepatocytes in the study of cytokine induced acute-phase protein secretion in vitro. Vet Immunol Immunopathol 53: $179-184$

Ametaj BN 2005: A new understanding of the causes of fatty liver in dairy cows. Adv Dairy Technol 17: 97-112

Ametaj BN, Bradford BJ, Bobe G, Nafikov RA, Lu Y, Young JW, Beitz DC 2005: Strong relationships between mediators of the acute phase response and fatty liver in dairy cows. Can J Anim Sci 85: 165-175

Berkova N, Lemay A, Dresser DW, Fontaine JY, Kerizit J, Goupil S 2001: Haptoglobin is present in human endometrium and shows elevated levels in the decidua during pregnancy. Mol Hum Reprod 7: 747-754

Curtius HCH 1974: Marc Rorh Clinical Biochemistry II. De Gruyter, 1034 pp

De Villiers WJ, Louw JP, Strachan AF 1990: C-reactive protein and serum amyloid-A protein in pregnancy and labour. Br J Obstet Gynaecol 97: 725-730

Drackley JK, Overton TR, Douglas GN 2001: Adaptations of glucose and long-chain fatty acid metabolism in liver of dairy cows during the periparturient period. J Dairy Sci 84 (E Suppl): E100-E112

Drackley JK, Janovich-Guretzky NA, Loor JJ 2007: Linkages between metabolism and the immune system. In: Fürll M: Production Diseases In Farm Animals. 13th International Conference, Leipzig: 214-227

Elitok B, Kabu M, Elitok ÖM 2006: Evaluation of liver function tests in cows during periparturient period. F Ü Sağlik Bil Dergisi 20: 205-209

Gatzka C, Bremerich D, Kaufmann M, Ahr A 2002: Isolated decrease in haptoglobin during pregnancy: diagnosis by chance or pathological? Zentralbl Gynakol 124: 120-122

Hachanberg S, Weinkauf C, Hiss S, Sauerwein H 2007: Evaluation of classification modes potentially suitable to identify metabolic stress in healthy dairy cows during the peripartal period. J Anim Sci 85: 1923-1932

Hardardottir I, Grunfeld C, Feingold KR 1994: Effects of endotoxin and cytokines on lipid metabolism. Curr Opin Lipidol 5: 207-215

Harris HW, Brady SE, Rapp JH 2002: Hepatic endosomal trafficking of lipoprotein-bound endotoxin in rats. J Surg Res 106: 188-195

Hirvonen J, Huszenicza G, Kulcsar M, Pyörälä S 1999: Acute-phase response in dairy cows with acute postpartum metritis. Theriogenology 51: 1071-1083

Jacobsen S 2003: The bovine acute phase response to endotoxin and Gram-negative bacteria. Ph.D. thesis, Copenhagen, Denmark, $162 \mathrm{pp}$

Kováč G, Bajová V, Bíreš J 2001: Diseases of cattle. (In Slovak) M\&M, Prešov, 874 pp

Kováč G, Popelková M, Tkáčiková L, Burdová O, Ihnát O 2007: Interrelationship between somatic cell count and acute phase proteins in serum and milk of dairy cows. Acta Vet Brno 76: 51-57

Krakowski L, Zdzisińska B 2007: Selected cytokines and acute phase proteins in heifers during the ovarian cycle course and in different pregnancy periods. Bull Vet Inst Pulawy 51: 31-36

Kushibiki S, Hodate K, Ueda Y, Shingu H, Mori Y, Itoh T, Yokomizo Y 2000: Administration of recombinant bovine tumor necrosis factor- $\alpha$ affects intermediary metabolism and insulin and growth hormone secretion in dairy heifers. J Anim Sci 78: 2164-2171

Kushibiki S, Hodate K, Shingu H, Hayashi T, Touno E, Shimoda M, Yokomizo Y 2002: Alterations in lipid metabolism induced by recombinant bovine tumor necrosis factor-alpha administration to dairy heifers. J Ani Sci 80: 2151-2157

Levels JH, Abraham PR, Van Den Ende A, Van Deventer SJ 2001: Distribution and kinetics of lipoprotein-bound endotoxin. Infect Immun 69: 2821-2828

Petersen HH, Nielsen JP, Heegaard PMH 2004: Application of acute phase protein measurements in veterinary clinical chemistry. Vet Res 35: 163-187

Piňeiro M, Alava MA, Lampreave F 2003: Acute phase proteins in different species: a review. Fourth European Colloquium on Acute Phase Proteins, Segovia, Spain: 77-82 
Regassa F, Noakes DE 1999: Acute phase protein response of ewes and the release of PGFM in relation to uterine involution and the presence of intrauterine bacteria. Vet Rec 144: 502-506

Uchida E, Katoh N, Takahashi K 1993: Appearance of haptoglobin in serum from cows at parturition. J Vet Med Sci 55: 893-894

Young CR, Eckersall PD, Saini PK, Stanker L 1995: Validation of immunoassays for bovine haptoglobin. Vet Immunol Immunopathol 49: 1-13 